\title{
TRANSFORMATIONS AND PERSPECTIVES OF THE LIVING CONDITIONS OF CZECH AND SLOVAK SENIORS WITH AN EMPHASIS ON SINGLE-PERSON HOUSEHOLDS
}

\author{
NAĎA HAZUCHOVÁ ${ }^{1}$ - JANA STÁVKOVÁ ${ }^{2}$ - L'UDMILA NAGYOVÁ ${ }^{3}-$ \\ ZUZANA POLÁKOVÁ ${ }^{4}$ - SOŇA VÁVROVÁ ${ }^{5}$
}

${ }^{1}$ Department of Marketing and Trade, Faculty of Business and Economics, Mendel University in Brno, Czech Republic

E-mail: nada.hazuchova@mendelu.cz

${ }^{2}$ Department of Marketing and Trade, Faculty of Business and Economics, Mendel University in Brno, Czech Republic

${ }^{3}$ Department of Marketing and Trade, Faculty of Economics and Management, Slovak University of Agriculture, Nitra, Slovak Republic

${ }^{4}$ Department of Statistics and Operations Research, Faculty of Economics and Management, Slovak University of Agriculture, Nitra, Slovak Republic

${ }^{5}$ Department of Social Work, Faculty of Social Studies, University of Ostrava, Czech Republic

The paper looks at the life situation of Czech and Slovak seniors between 2005 and 2016. The aim is to analyze data from the national standardized surveys (EU-SILC) and, based on the analyzed data, describe living conditions (an objectively measured standard of living and poverty rate) and subjective life satisfaction with an emphasis on seniors living in single-person households. The results show a large increase in the number of single-person households. The analysis of Czech households' income situation showed that the per-member monthly income for the whole population was similar to the average per-member income in households of seniors, while the group of the elderly living in single-person households appeared to be the most vulnerable one in terms of income. The differences between the seniors' incomes and expenditures indicated that about $40 \%$ of this data segment's members lived near the poverty line, while the most endangered segment members were seniors from single-person households.

Keywords: senior, single-person household, living conditions, social exclusion, poverty

JEL-codes: I30, I32, Z13 


\section{INTRODUCTION}

The aging of the European and, therefore, the Czech and Slovak populations, is an unwavering developmental trend which must be taken into account by the EU and member states authorities when preparing social and public policy programs (see e.g. Potůček - Radičová 1999; Veselý - Nekola 2008; Nekola et al. 2011). Population aging in developed countries is becoming not only a European, but, above all, a global social challenge that needs to be reflected in social policies worldwide. This is confirmed by the available data (CZSO 2016a). The ageing of societies is a gradual process that is not easily noticeable now, but everyone will feel its impact in the future (OECD 2015).

European citizens older than 65 years represented $18.5 \%$ of the entire European population, while $5.1 \%$ were people older than 80 years. In the Czech Republic, $17.4 \%$ of citizens were over 65 , which was slightly below the European average. Likewise, in the Slovak Republic $14 \%$ of people were over 65 years in the population. People aged 80 or more accounted for $3.9 \%$ of the Czech population and $3 \%$ of the Slovak population (CZSO 2016b). Two main reasons of ageing can be found - fewer children are being born and people are living longer (OECD 2015). In connection with the above, we can state that in 2014 the numbers of citizens older than 80 years were lower in the Czech and Slovak population than in the European Union as a whole. From this we can infer that the life expectancy in the Czech Republic (76.1 years) and in the Slovak Republic ( 75 years) is slightly below the European average (78.5 years). (CZSO 2016b). However, the two countries are doing a little bit better in terms of life expectancy compared to the neighbouring countries that were also members of the former Eastern Bloc.

The group of seniors does not represent a homogeneous age-defined group; there are several other factors that further differentiate this group. One of the most important factors is the character of the seniors' household, in terms of the number of members, as well as the income level. Life style and personal satisfaction, as subjectively perceived by the seniors, are derived not only from their income situation, but also from their health status, family background and other social factors. The focus is on seniors living in single member households, however, this does not necessarily mean they are lonely, nor that they feel alone.

A mature society should be prepared for social changes in the elderly group and create conditions for active ageing that would prevent social exclusion of people from the target group. The aim should be to enable seniors to stay in their natural social environments, that is, in the environment and space in which they used to live during their working life.

In connection with the above, the paper offers a new perspective through a probe into the development of the living conditions of Czech and Slovak seniors 
over the course of a decade. The aim of this paper is to describe living conditions (objectively measured living standards and poverty rates), and subjectively perceived life satisfaction of Czech and Slovak seniors with an accent on single-person households, over the period between 2005 and 2016, including the positive and the negative economic developments, based mainly on the analysis of data from the European Union's Statistics on Income and Living Conditions survey. The net income of a household per a member is the basic variable for assessing the income situation. The poverty rate and the material deprivation is expressed according to the EU's methodology. A binary logistic regression is applied in order to evaluate the meaningfulness of life among seniors.

\section{LITERATURE REVIEW}

Income poverty, where insufficient income does not allow a household to achieve the required living standard, is a problem that even countries in the European Union have to deal with (Stiglitz et al. 2009). Chakravarty (2010) explains that as a result of income inequality among households, a section of the population that does not meet their needs due to a lack of money can be identified. Households from this group live in material deprivation and at risk of poverty, sometimes even in social exclusion (Halleröd - Larsson 2008).

According to many Czech and Slovak authors (e. g. Piscová 2014; Kubalčíková 2015; Vávrová 2015; Šprocha et al. 2015), seniors are becoming a group at risk of social exclusion, not only due to their deteriorating health conditions, but mainly because of their declining socioeconomic status. Kis and Gábos (2015) state that characteristics such as age or household composition have been found to play an important role in predicting dimensions of poverty.

Changes in economic activities during the transition from working-age to the post-productive age have a major impact on the standard of living for most people. The reduction of financial income is reflected in the changing social status. There are two main causes of the living situation deterioration of seniors who live in single-person households: (1) they lived in a single-person household during the productive age or (2) they lost their life partners. The change in income (when a person becomes a recipient of a retirement pension) can be so pronounced that a senior living in a single-person household is forced to change their lifestyle. They begin to experience feelings of uncertainty, inferiority, as well as fear of the future. This may result in isolation from society (Gruss 2009). Vagnerová (2007) describes this isolation as a social alienation. If one lives alone and does not have contacts with family or friends, they can easily get separated from society and fall into social isolation. If this feeling of social belonging is disrupted, it leads to 
"social exclusion" (Čevela et al. 2012). Gruss (2009) states that a senior should have a sense of belonging, be in touch with their loved ones and peers who deal with similar problems and have gone through similar life situations. If seniors experience a disease or some of their functions are impaired, they may get into a difficult life situation that they are forced to deal with in some way. The ultimate solution may be to separate such seniors on an institutional basis (homes for seniors or other social care facilities).

The increase in the proportion of the elderly in the European population, according to Keller (2009), leads to a worsening of the ratio between economically active people and people in the post-productive age, which brings unexpected difficulties. Among those at risk of social exclusion, Mareš et al. (2008) specifically pinpointed the elderly living alone. In the last decade, the issue of autonomy, social relations in an old age, housing and poverty of Czech and Slovak seniors has been researched by both Czech authors (see Sýkorová 2007; Sýkorová et al. 2014a; Sýkorová et al. 2014b) and Slovak researchers (Potančoková 2015). These authors also focused on financial self-sufficiency.

Likewise, international and national documents prove that the European Union has been actively preparing for its population's ageing for at least 15 years (MPSV 2002; 2014; 2015). Activities aimed at supporting the elderly associated with preventing social exclusion are inevitable in public policy, since in 2014 (which is the last year of our primary data) there were almost 1,834,000 Czech and 756,879 Slovak citizens older than 65 years. In 2006, the Government Council for Older Persons and Population Ageing was established in the Czech Republic, which acts as a permanent advisory body to the government aiming to create conditions for healthy, active and dignified ageing, as well as support the active involvement of the elderly in the economic and social development of society, in the context of demographic development (MoLSA 2016). It aligns its activities with the World Health Organization, which issued the Active Ageing strategy for the Second United Nations World Assembly on Aging (Holmerová et al. 2006).

The concept of active aging, according to the WHO, includes the feeling of physical, mental and social well-being, involvement in society, a sense of independence, security and care. Another important point of active ageing is intergenerational solidarity (WHO 2002). This factor is also mentioned by the European Union, which follows the views of the EU population based on surveys. Active ageing strategies, as a result of the consensus of many experts, should become a starting point for public and social policies at the municipal, regional and country level. Boudiny (2013) explains that a positive relationship between the prolongation of the active working age and the positive health consequences can be the motivation for seniors to be active and stay at work. Their income situation and possible better living conditions can be the main reasons for the elderly to 
consider active age prolongation, but other reasons can include the need to view oneself as useful, a chance to participate in society, and the effort not to lose social contacts (Pisarev 2006; Bradley 2004).

\section{METHODOLOGY}

The data for assessing the living standards of seniors are from the European Union's Statistics on Income and Living Conditions project (EU-SILC), which deals with the income of households and individuals and their living conditions. According to Regulation (EC) No 1177/2003 of the European Parliament and of the Council (EUR-Lex 2013), the survey is mandatory for all member states of the European Union. In the Czech Republic, it is implemented by the Czech Statistical Office, in Slovakia by the Statistical Office of Slovak Republic. Survey results from all member states are available on the Eurostat website. The main objective of the survey is to obtain representative data, giving a picture of the income situation of households, data on the quality and financial demands of housing, equipment for long-term use, but also on subjective feelings about the living conditions of individuals (Eurostat 2018a).

For a comprehensive assessment of the life situation of Czech and Slovak seniors with an accent on single-person households, we applied the net income of their households and its utilization. Senior households that are examined are determined as households where the activity status of members of the household is retired. It is not restricted by their age because the age of retirement is different during the reference period in different countries (the only exception is in Table 4 where an age limit of 65 years was used). The analyzed data sample was extrapolated to the whole population of the Czech Republic and Slovakia.

Household income data were used to calculate descriptive characteristics, including the median, and those were arranged into deciles. The authors calculated cumulative values and created a new distribution function based on decile limits. Relative income poverty is assessed on the basis of the poverty line set at $60 \%$ of the median value. Important information on income inequality is demonstrated by the Gini coefficient. For calculating the Gini coefficient, the Brown formula was used. This method also requires ordering income values from the lowest to the highest ones. Mathematically, the formula below is used to express this value:

$$
G=\left|1-\sum_{k=0}^{k=n-1}\left(X_{k+1}-X_{k}\right)\left(Y_{k+1}+Y_{k}\right)\right|
$$


where $X_{k}$ is the cumulative value of the population variable and $Y_{k}$ is the income variable. The values of Gini coefficient range from 0 to 1 , with the interpretation that values closer to 0 represent greater income equality.

Another feature crucial for assessing the income situation is the indicator of the depth of household poverty in society. This indicator theoretically informs about the amount of funds that households need to get out of the poverty zone, i.e. above the poverty line. The entry quantities for the calculation are the average income of households at risk of poverty ("a") and the poverty line ("A"). Based on the relationship (A-a) / A, the Sen coefficient or the poverty gap index (income deficit of households) ranging from 0 to 1 is obtained. The values close to zero indicate moderate poverty and the values approaching one mean deep poverty.

In the context of non-income poverty indicators, the term material deprivation is used. If a person is materially deprived, it means that they live without what is considered necessary and recognized by society. At the initiative of the European Commission, a list of 9 items was prepared in 2012 to determine whether the household is materially deprived or not. If a household claims they lack three or more of the items in the list, they fall into the group of the materially deprived. The individual factors are (Eurostat 2018b): (1) ability to pay rent and bills; (2) a sufficiently heated house; (3) ability to pay unexpected expenses; (4) ability to eat meat or fish every other day; (5) the ability to afford a weeklong vacation away from home; (6) owning a car; (7) owning a washing machine; (8) owning a colour $\mathrm{TV}$; (9) owning a phone.

In 2010, the concept of deprivation was also applied in the area of housing. If the household is "overcrowded" and reports one of the four issues below, it is a household deprived of quality housing. The issues are the following (Eurostat 2017): (1) problem with humidity in the apartment; (2) a bathroom is not a part of the apartment; (3) a toilet is not a part of the apartment; (4) the apartment is dark.

In addition to household income, attention is also paid to household spending. The consumption data were drawn from the Czech Statistical Office and the Statistical Office of Slovak Republic, from the Household Budget Surveys (HBS) according to the COICOP (Classification of Individual Consumption by Purpose) classification.

The data obtained are further used to monitor the life satisfaction amongst elderly people. The satisfaction of households in their life was an ad hoc module in the EU-SILC in 2013. As an example of a possible method for analyzing the determinants of life satisfaction, the paper applies a binary logistic regression on the population of the Czech and Slovak Republics. Because of several factors affecting the satisfaction of seniors, the relationship between the achieved education, the subjectively perceived level of meaningfulness of life and the life satisfaction is covered by this study. Education has been partitioned into 9 grades - from the 
lowest (primary education) to the highest (university degrees) - based on the CZ-ISCED Classification of Education (CZSO 2016c). The meaningfulness of life has been evaluated on a scale from 1 to 10 , where 10 means that an individual has a clearly defined meaning in their life. The analysis was performed using the binary logistic regression. The satisfaction index was defined with a 6-degree scale which was transcribed to a binary variable with the "satisfied" (originally: very satisfied, rather satisfied and satisfied) and "dissatisfied" (originally: very dissatisfied, dissatisfied and rather dissatisfied) values. This frequency concept of satisfaction is therefore a dependent variable expressed by values of 0 and 1 . The independent variables are education and meaningfulness. The reference category is the lowest degree of education and meaningfulness. It is assumed that the random variable has a binomial distribution with the $\pi$ parameter, which corresponds to the probability of the resulting value of 1 and changes monotonously with the value of the independent variable. The resulting model is an estimate of this parameter with dependency on $x$. After editing, it takes the form below:

$$
\log \frac{\pi(x)}{1-\pi(x)}=\alpha+\beta x
$$

The left-hand side of the equation is called logit. The $\alpha$ and $\beta$ values are regression coefficients calculated by the use of the iterative least-square method.

\section{RESULTS}

The results of the EU-SILC sample survey, according to a uniform methodology, allow the representation of selected population groups to be converted to the whole basic set of the Czech Republic and Slovakia. This conversion based on the household weight is shown in Table 1, which represents the expected demographic change in the Czech Republic with an increasing number of seniors in the population (over the past 12 years by about $2.7 \%$ ), and in Slovakia with a decrease of $2.6 \%$.

\subsection{The living standards of Czech and Slovak seniors}

To assess the living standard of seniors and their economic conditions of life, we use the data presented in Table 2, which contains not only data on households of seniors and individuals, but also data on households representing the whole population of the Czech Republic and Slovakia. The table shows that differences in income per household member are very small between different household groups (excluding the households of the unemployed). The average monthly income of 


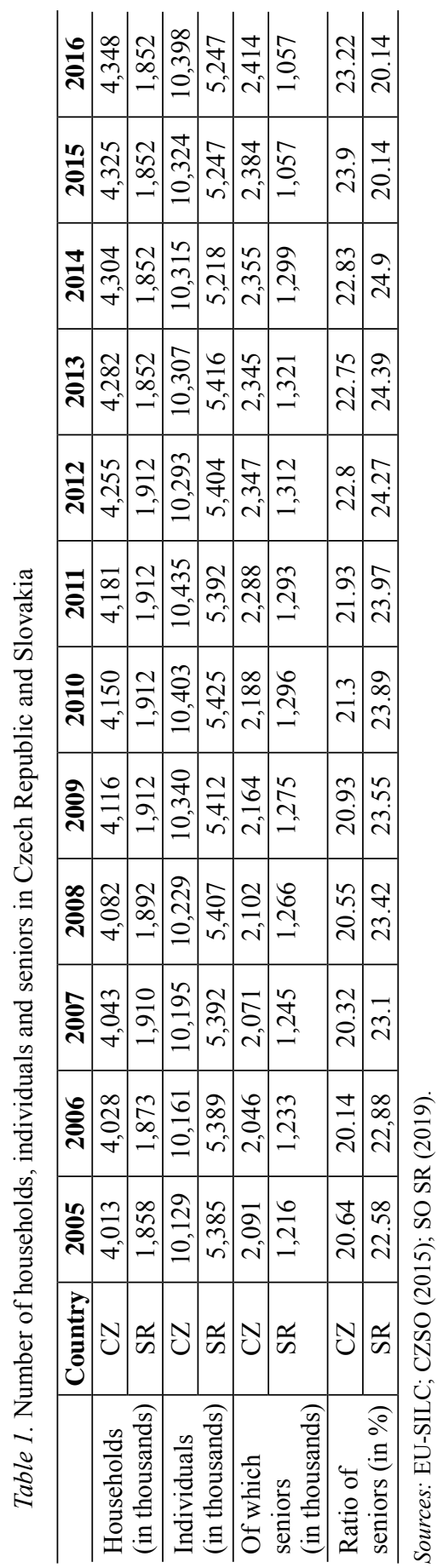




\begin{tabular}{|c|c|c|c|c|c|c|c|c|c|c|c|c|c|}
\hline$\frac{0}{\dot{\nu}}$ & $\frac{a}{n}$ & F & 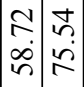 & \begin{tabular}{l}
$\infty$ \\
\hdashline \\
$\infty$
\end{tabular} & बे & $\mid$\begin{tabular}{l|l}
$n$ & $\infty$ \\
$\infty$ & $\infty$ \\
$\infty$ & $n$ \\
$n$ & $n$
\end{tabular} & 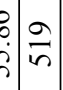 & ; & 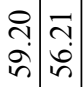 & $\underset{\mathcal{J}}{\stackrel{f}{2}}$ & $\stackrel{\substack{\sim \\
\sim}}{ }$ & 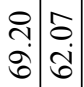 & \\
\hline กี่ & 文 & $\stackrel{\overbrace{}}{f}$ & \begin{tabular}{|c|c}
$\infty$ \\
0 \\
$\dot{0}$ \\
$\dot{n}$ \\
$\infty$ \\
$\infty$ \\
0
\end{tabular} & 字 & \& & 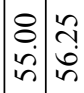 & $\begin{array}{c}\hat{n} \\
\dot{0}\end{array}$ & ஓे & 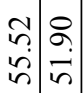 & $\vec{\sim}$ & $\stackrel{\infty}{\infty}$ & \begin{tabular}{c|c}
0 & $\delta$ \\
& $\alpha$ \\
0 & 8 \\
\end{tabular} & \\
\hline ت্ণ & $\begin{array}{c}\Re \\
⿱ 亠 乂 \\
+\end{array}$ & ஓे & 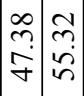 & 市 & \& & 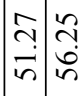 & 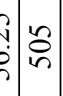 & $\stackrel{\sim}{\sim}$ & \begin{tabular}{c|c}
$m$ & \\
0 & \\
$\dot{n}$ & $\dot{b}$
\end{tabular} & $\approx$ & $\stackrel{\infty}{\stackrel{\infty}{\sim}}$ & 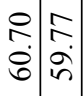 & \\
\hline$\stackrel{n}{\tilde{N}}$ & $\bar{\nabla}$ & $\underset{m}{\stackrel{0}{m}}$ & \begin{tabular}{l|c}
$\partial$ \\
$\hat{f}$ \\
$\dot{f}$
\end{tabular} & $\vec{\infty}$ & बे & 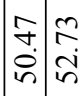 & 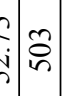 & $\frac{\partial}{\sigma}$ & 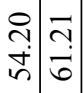 & $\approx$ & $\stackrel{n}{\sim}$ & \begin{tabular}{c|c}
$m$ & $n$ \\
$m$ & 0 \\
$\infty$ & $\infty$ \\
$n$ & $\infty$
\end{tabular} & \\
\hline 고ำ & $\mid \begin{array}{l}t \\
d\end{array}$ & $\ddot{0}$ & \begin{tabular}{|l|l|}
$\infty$ & $\infty$ \\
$\dot{\gamma}$ & $\infty$ \\
$\dot{\gamma}$ & $\dot{f}$
\end{tabular} & $\vec{\nabla}$ & $\frac{0}{m}$ & 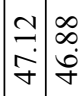 & 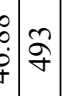 & in & \begin{tabular}{l|l} 
\pm & $\tilde{\vdots}$ \\
$\dot{\vec{n}}$ & $\hat{n}$
\end{tabular} & ڤે & $\underset{⿱}{\stackrel{\Delta}{N}}$ & 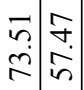 & \\
\hline $\bar{\nabla}$ & $\begin{array}{l}n \\
\sim \\
\sigma\end{array}$ & ర్ర & 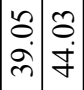 & $\stackrel{+}{\checkmark}$ & ర్ర & \begin{tabular}{l|l}
$\vec{\infty}$ & $\vec{\forall}$ \\
$\dot{\forall}$ & $\vec{f}$
\end{tabular} & $\begin{array}{l}\vec{f} \\
\dot{f} \\
\stackrel{\overbrace{}}{f}\end{array}$ & $\frac{\hat{n}}{n}$ & \begin{tabular}{l|l}
$\dot{t}$ & $\hat{\sigma}$ \\
$\dot{f}$ & 0 \\
$\dot{\sigma}$
\end{tabular} & $\stackrel{\stackrel{\sim}{\sim}}{\sim}$ & $\vec{\sim}$ & 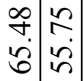 & \\
\hline 울 & $\sqrt{7}$ & 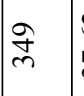 & 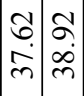 & $\stackrel{q}{f}$ & $\hat{n}$ & $\begin{array}{l}\hat{n} \\
\hat{n} \\
\dot{n} \\
\infty \\
\bar{n}\end{array}$ & 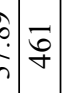 & $\underset{n}{N}$ & \begin{tabular}{l|l}
$\tilde{r}$ & \multicolumn{0}{c}{} \\
$\vec{\gamma}$ & $\dot{\sigma}$
\end{tabular} & $\stackrel{\infty}{\sim}$ & $\ddot{\mathscr{v}}$ & 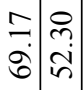 & \\
\hline ஓे & 导 & $\bar{n}$ & $\begin{array}{ll}0 & \hat{n} \\
m \\
\dot{m} \\
\tilde{m}\end{array}$ & $\frac{\infty}{\gamma}$ & 孚 & 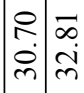 & 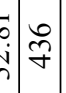 & $\hat{b}$ & 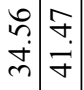 & $\frac{m}{\sim}$ & ๙ે & 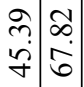 & \\
\hline ஜٌ & ช̂ & ñ & 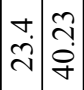 & $\begin{array}{l}\dot{\alpha} \\
\infty\end{array}$ & $\frac{m}{m}$ & $\stackrel{\substack{n\\
}}{\hat{N}}$ & \begin{tabular}{|ll} 
\\
$j$
\end{tabular} & $\hat{m}$ & \begin{tabular}{l|l}
$\tilde{n}$ & $\infty$ \\
& \multirow{n}{n}{} \\
\end{tabular} & 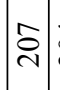 & ষ্ & 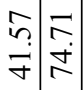 & \\
\hline ڤે̀े & $\underset{n}{\mathbb{N}}$ & ๙ి & 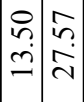 & 吕 & $\stackrel{n}{\grave{\lambda}}$ & 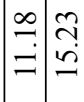 & 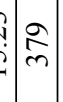 & $\frac{N}{m}$ & 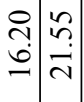 & $\tilde{\infty}$ & ले & \begin{tabular}{c|c}
$\infty$ & 0 \\
$n$ & $n$ \\
& $n$ \\
& $m$
\end{tabular} & \\
\hline ठั. & $\stackrel{m}{m}$ & 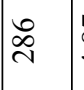 & \begin{tabular}{|c|c|c|}
$\hat{\infty}$ & $n$ \\
$\dot{\gamma}$ & $\infty$ \\
&
\end{tabular} & $\stackrel{m}{m}$ & 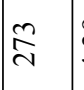 & 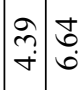 & 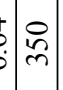 & $\underset{\infty}{\sim}$ & 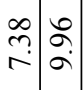 & $\stackrel{\infty}{=}$ & $\stackrel{\overbrace{}}{\sim}$ & 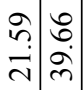 & \\
\hline ํㅗㅇ & $\underset{\approx}{\approx}$ & $\bar{\sim}$ & 1 & શి & $\stackrel{\circ}{\sim}$ & 1 & $\left|\begin{array}{l}0 \\
\sim \\
m\end{array}\right|$ & $i n$ & 1 & 㞷 & $\stackrel{J}{I}$ & 1 & \\
\hline ن & N & $\stackrel{\approx}{\infty}$ & N)胥 & N & $\underline{\sim}$ & N) & 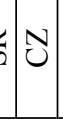 & $\tilde{\sim}$ & N & N & $\frac{\mathscr{r}}{\sim}$ & 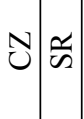 & $\begin{array}{l}\stackrel{\sigma}{\vec{D}} \\
\underset{\tilde{d}}{\tilde{d}}\end{array}$ \\
\hline & 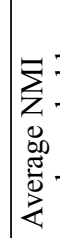 & 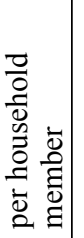 & $\begin{array}{l}\text { o } \\
\Xi \\
\Xi \\
0 \\
0 \\
0 \\
0\end{array}$ & 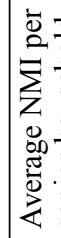 & 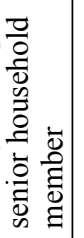 & $\begin{array}{l}0 \\
0 \\
\Xi \\
\Xi \\
0 \\
0 \\
0\end{array}$ & 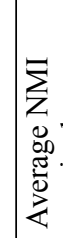 & 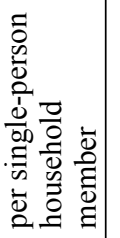 & $\begin{array}{l}\text { o } \\
\Xi \\
\Xi \\
0 \\
0 \\
0 \\
0\end{array}$ & 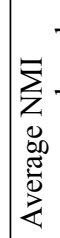 & 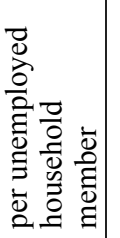 & $\begin{array}{l}20 \\
\Xi \\
\Xi \\
5 \\
0 \\
0 \\
0\end{array}$ & 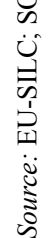 \\
\hline
\end{tabular}


Czech households calculated to a single member has reached $€ 435$ during the whole period, ${ }^{1}$ and $€ 355$ for the Slovak households. As for seniors' households, the amount was $€ 430$ in the Czech Republic, and $€ 347$ in Slovakia. Households of the unemployed in the Czech Republic earned on average $€ 219$ and $€ 265$ in Slovakia. In Slovakia, the average net financial income per household member grew faster, but this does not apply to seniors' households. As for the unemployed, the income per member varied during the reference period, depending on the economic development of the society.

Income inequality is measured by Gini coefficient. The following indicators of income inequality have been calculated from equalized income. In 2005, the Gini coefficient for the senior's group reached the value of 0.167 in Czech Republic, and 0.253 in Slovakia, and for all households in the Czech Republic the value was 0.261 and 0.282 for Slovakia. For the seniors group, income differentiation slightly increased over the monitored years, but in the last years it remained roughly at the same level with a slight decrease. Thus, we can say that income inequalities in the senior's group are almost negligible. This fact attests to the accent of solidarity in the pension system, due to the application of the principle of merit. Over the past 12 years, the Gini coefficient has had a declining trend, i.e. the differences in households' incomes were narrowing.

The comparison of income and expenditures (Table 3) contributes to better understanding the living standards of seniors, i.e. satisfaction of their daily needs.

From the data presented in Table 3, we could say that in all the monitored years, the income of the Czech seniors exceeded their expenditures, and the situation for Slovak households is similar, except for the years 2005 and 2006. At this point, however, it should be emphasized that these are average values gained from the EU-SILC and Family Budget surveys. The results of the frequency distribution of seniors' income (for example in 2014) show that seniors' households are predominantly in the first to the third deciles, therefore, the excess of income over expenditures is not that significant for seniors.

Table 3. Monthly income and expenditure of Czech and Slovak seniors (in euro)

\begin{tabular}{l|c|c|c|c|c|c|c|c|c|c|c|c|c}
\hline & Country & $\mathbf{2 0 0 5}$ & $\mathbf{2 0 0 6}$ & $\mathbf{2 0 0 7}$ & $\mathbf{2 0 0 8}$ & $\mathbf{2 0 0 9}$ & $\mathbf{2 0 1 0}$ & $\mathbf{2 0 1 1}$ & $\mathbf{2 0 1 2}$ & $\mathbf{2 0 1 3}$ & $\mathbf{2 0 1 4}$ & $\mathbf{2 0 1 5}$ & $\mathbf{2 0 1 6}$ \\
\hline \multirow{2}{*}{ Income } & $\mathrm{CZ}$ & 320 & 334 & 356 & 389 & 418 & 445 & 454 & 471 & 481 & 484 & 496 & 508 \\
\cline { 2 - 16 } & $\mathrm{SR}$ & 256 & 273 & 295 & 313 & 340 & 353 & 362 & 376 & 391 & 400 & 400 & 399 \\
\hline \multirow{2}{*}{ Expenditures } & $\mathrm{CZ}$ & 287 & 301 & 312 & 314 & 329 & 360 & 372 & 374 & 386 & 390 & 387 & 384 \\
\cline { 2 - 14 } & $\mathrm{SR}$ & 257 & 279 & 280 & 297 & 287 & 311 & 319 & 321 & 328 & 317 & 329 & 322 \\
\hline \multirow{2}{*}{ Difference } & $\mathrm{CZ}$ & 33 & 33 & 44 & 74 & 89 & 85 & 81 & 97 & 95 & 94 & 110 & 124 \\
\cline { 2 - 12 } & $\mathrm{SR}$ & -1 & -6 & 15 & 16 & 53 & 42 & 43 & 55 & 63 & 83 & 71 & 77 \\
\hline
\end{tabular}

Sources: EU-SILC; CZSO; SO SR (2019).

The exchange rate for the Czech crown was $1 \mathrm{EUR}=26.467 \mathrm{CZK}$. 


\subsection{Poverty of Czech and Slovak seniors}

Within the context of poverty, we focus on (1) the extent to which Czech and Slovak seniors are at risk of poverty, (2) its depth and (3) material deprivation.

The poverty line has been precisely defined by the EU definition as $60 \%$ of the median income per equivalent household member. After the conversion to households from the EU-SILC survey, we found that the number of seniors at risk of poverty in the Czech Republic was at first increasing between the years 2005 and 2008, then decreasing, and from 2014 increasing again. The increase in total is from $6.1 \%$ to $8.1 \%$ - see Table 4 . In Slovakia, the indicator of senior's poverty rate was also first increasing until 2008 and then decreasing and fluctuating. In 2016 , the rate dropped to $6.0 \%$.

We need to notice that this senior's poverty rate in Table 4 is calculated just in the group of senior households in order to see the development of this indicator. If we calculate the poverty rate for all households we can get the value $9.7 \%$ in the Czech Republic in 2016. But this value is not comparable to senior's poverty rate because of the different base of households. The important fact is that this group of $9.7 \%$ of all Czech households experiencing poverty is composed also from senior's households. Thirty-five percent of Czech households living in poverty were senior's households in 2016 and $20.1 \%$ of the Czech poor households is composed of one adult age 65 or more. The development of this share is shown in Table 4. One fifth of endangered households are this type of a household in both countries.

Poverty has a number of causes and hence also a number of forms for its expression. Sen's poverty index was used to express how much money the household needs to get in order to move above the poverty line. Table 5 shows the poverty line expressed monthly in euro per equalised member of a household in the Czech Republic and Slovakia. Based on the average net financial income and the poverty line, we can identify similarities in both countries.

It is clear, therefore, that households in the whole group need more money to get beyond the poverty line than households of seniors. This fully corresponds

Table 4. Seniors at risk of poverty

\begin{tabular}{|c|c|c|c|c|c|c|c|c|c|c|c|c|c|}
\hline & Country & 2005 & 2006 & 2007 & 2008 & 2009 & 2010 & 2011 & 2012 & 2013 & 2014 & 2015 & 2016 \\
\hline \multirow{2}{*}{$\begin{array}{l}\text { Seniors } \\
\text { at risk of } \\
\text { poverty }\end{array}$} & $\mathrm{CZ}$ & 6.1 & 6.8 & 6.3 & 8.0 & 7.1 & 6.6 & 6.7 & 6.4 & 6.1 & 6.9 & 7.4 & 8.1 \\
\hline & & 6.9 & 8.1 & & 9.7 & 8.9 & 6.7 & 6.3 & 7.7 & 6.6 & 6.7 & 6.2 & 6.0 \\
\hline \multirow{2}{*}{$\begin{array}{l}\text { One adult } \\
\text { over } 65 \text { in } \\
\text { a household }\end{array}$} & & 18.7 & 19.2 & 18.1 & 19.1 & 19.2 & 17.4 & 19.0 & 16.2 & 16.5 & 16.2 & 20.2 & 20.1 \\
\hline & SR & 22.8 & 19.1 & 18.2 & 21.5 & 20.0 & 23.4 & 25.1 & 24.1 & 21.3 & 20.4 & 21.2 & 22.7 \\
\hline
\end{tabular}

Source: EU-SILC; Eurostat (2019). 
with the reported income per household member. Using Sen's coefficient, we found that the entire household set reported a deeper poverty (both in the Czech Republic and Slovakia, the indicator ranged from 0.21 to 0.23 ) than the segment of seniors' households (the indicator ranged from 0.11 to 0.15 ).

Table 5. Depth of poverty (in euro)

\begin{tabular}{l|c|l|l|l|l|l|l|l|l|l|l|l|l}
\hline & Country & $\mathbf{2 0 0 5}$ & $\mathbf{2 0 0 6}$ & $\mathbf{2 0 0 7}$ & $\mathbf{2 0 0 8}$ & $\mathbf{2 0 0 9}$ & $\mathbf{2 0 1 0}$ & $\mathbf{2 0 1 1}$ & $\mathbf{2 0 1 2}$ & $\mathbf{2 0 1 3}$ & $\mathbf{2 0 1 4}$ & $\mathbf{2 0 1 5}$ & $\mathbf{2 0 1 6}$ \\
\hline \multirow{2}{*}{ Poverty line } & $\mathrm{CR}$ & 255 & 270 & 290 & 318 & 343 & 352 & 356 & 362 & 365 & 374 & 386 & 404 \\
\cline { 2 - 13 } & $\mathrm{SR}$ & 188 & 212 & 245 & 269 & 284 & 306 & 315 & 326 & 337 & 341 & 343 & 347 \\
\hline
\end{tabular}

Source: EU-SILC; SO SR (2019).

Material deprivation is one of the forms of poverty. Non-financial poverty of seniors is expressed by the data on material deprivation shown in Table 6. This indicator has been included in the EU-SILC survey since 2009. Materially deprived households are those lacking three or more of the nine items defined by the EU Commission, as described in the Methodology.

Table 6. Material deprivation

\begin{tabular}{|c|c|c|c|c|c|c|c|c|c|}
\hline & Country & 2009 & 2010 & 2011 & 2012 & 2013 & 2014 & 2015 & 2016 \\
\hline \multirow{2}{*}{$\begin{array}{l}\text { Share of deprived } \\
\text { households }\end{array}$} & $\mathrm{CZ}$ & 16.7 & 16.0 & 17.0 & 18.3 & 17.4 & 17.2 & 14.6 & 13.8 \\
\hline & SR & 24.5 & 24.9 & 22.0 & 22.7 & 23.4 & 22.2 & 20.3 & 19.1 \\
\hline \multirow{2}{*}{$\begin{array}{l}\text { Share of deprived } \\
\text { senior households } \\
\text { within all senior } \\
\text { households }\end{array}$} & $\mathrm{CZ}$ & 17.11 & 16.20 & 17.17 & 20.36 & 18.34 & 16.94 & 15,00 & 12.54 \\
\hline & SR & 30.0 & 28.2 & 23.5 & 27.4 & 26.5 & 25.4 & 25.0 & 22.9 \\
\hline
\end{tabular}

Source: EU-SILC; SO SR (2019).

Shares of deprived households, as well as deprived households of seniors, have been falling throughout the analysed period. However, the share of deprived single-person senior households is high (about $24.6 \%$ of single-person senior households in Slovakia were deprived in 2016 and the same indicator is $13.3 \%$ in the Czech Republic). These results also confirm our assumption of a higher level of threat (by poverty) to seniors living in single-person households.

\subsection{Satisfaction with living standards}

Characteristics like the income situation and material deprivation of seniors as objective indicators of the living standards served as a basis for the calculation of the relative satisfaction of average senior households with their standard of living. However, in order to discover how the standard of living is perceived by the 
seniors themselves, in connection with the perceived meaningfulness of life and the achieved level of education as a decisive starting factor at the beginning of a life career, we also employ the binary regression analysis (see Table 7), which allows the interconnection of objective and subjective factors. The number of valid observations used in the regression is 4,776 seniors from the entire dataset which contained 5,526 seniors. The variable MEANINGFUL expresses the degree of meaningfulness of what seniors do in life with the a scale from 0 (no sense at all) to 10 (definitely makes sense) and the variable EDUCATION expresses 9 grades of the highest attained level of their education where 1 is the first level of a primary education, 2 is completed primary education, 3 is lower secondary education, 4 is completed secondary education, 5 is upper secondary education, 6 is post-secondary non tertiary education, 7 is tertiary education - bachelor's degree, 8 is tertiary education - master's degree, and 9 is a doctoral degree.

According to Wald's statistics, the most meaningful categories have statistically significant regression parameters (Sig. $<0.05$ ). The model accurately determined $82.1 \%$ of observations. Based on the determination coefficient (Nagelkerke R

Table 7. Binary regression analysis

\begin{tabular}{|c|c|c|c|c|c|c|c|}
\hline Variables & & B & S.E. & Wald & df & Sig. & $\operatorname{Exp}(B)$ \\
\hline \multirow{22}{*}{ Step $1^{\mathrm{a}}$} & MEANINGFUL & & & 593.248 & 10 & .000 & \\
\hline & MEANINGFUL (1) & -22.699 & 1338.979 & .000 & 1 & .986 & .000 \\
\hline & MEANINGFUL (2) & -22.709 & 11587.767 & .000 & 1 & .998 & .000 \\
\hline & MEANINGFUL (3) & -3.768 & .541 & 48.456 & 1 & .000 & .023 \\
\hline & MEANINGFUL (4) & -3.774 & .441 & 73.169 & 1 & .000 & .023 \\
\hline & MEANINGFUL (5) & -2.876 & .277 & 107.448 & 1 & .000 & .056 \\
\hline & MEANINGFUL (6) & -2.229 & .145 & 235.560 & 1 & .000 & .108 \\
\hline & MEANINGFUL (7) & -1.179 & .147 & 63.906 & 1 & .000 & .308 \\
\hline & MEANINGFUL (8) & -.184 & .139 & 1.746 & 1 & .186 & .832 \\
\hline & MEANINGFUL (9) & -.162 & .129 & 1.574 & 1 & .210 & .850 \\
\hline & MEANINGFUL (10) & .490 & .167 & 8.610 & 1 & .003 & 1.632 \\
\hline & EDUCATION & & & 17.842 & 9 & .037 & \\
\hline & EDUCATION (1) & 20.364 & 20096.271 & .000 & 1 & .999 & 698184528.580 \\
\hline & EDUCATION (2) & 1.322 & 1.825 & .525 & 1 & .469 & 3.752 \\
\hline & EDUCATION (3) & .401 & .489 & .675 & 1 & .411 & 1.494 \\
\hline & EDUCATION (4) & .367 & .484 & .575 & 1 & .448 & 1.444 \\
\hline & EDUCATION (5) & .642 & .487 & 1.742 & 1 & .187 & 1.901 \\
\hline & EDUCATION (6) & .084 & .580 & .021 & 1 & .884 & 1.088 \\
\hline & EDUCATION (7) & 1.668 & .964 & 2.993 & 1 & .084 & 5.304 \\
\hline & EDUCATION (8) & .210 & .819 & .066 & 1 & .798 & 1.233 \\
\hline & EDUCATION (9) & .775 & .501 & 2.395 & 1 & .122 & 2.171 \\
\hline & Constant & 1.012 & .492 & 4.235 & 1 & .040 & 2.752 \\
\hline
\end{tabular}

a. Variable(s) entered on step 1: MEANINGFUL. EDUCATION.

Source: authors 
Square 0.57), the model describes the data well. The defining values are shown in Table 7, column B. The column shows how many times a higher (or lower) chance for satisfaction a given category has compared with the first (lowest) category. The table shows that the higher the meaningfulness of life people have reported, the higher the chances of having a happy life. Thus, according to Frank1 $(2015 ; 2016 a ; 2016 b)$, it can be said that the degree of satisfaction is interconnected with the perceived meaningfulness of life. In terms of education, according to the results obtained, seniors with a university degree have a 5.3 or 2.2 times higher chance of being happy in their lives compared to the elderly with the lowest level of education.

\section{CONCLUSION}

Survey results show that the number of households in the Czech and Slovak Republics is slightly increasing, but the number of individuals stagnates. This fact highlights the increase in the number of single-person households. The presented results also show an increase in the number of senior households, as well as a high increase in single-person senior households. The only exceptions are the two last years in Slovakia, where the beginning of a potential decrease can be seen. However, the number of seniors living in separate single-person households is expected to increase in the future. This is an interesting finding that should be taken into account by the creators of public and social policy programs. Seniors living alone are becoming more threatened by social isolation and poverty.

The analysis of the income situation of Czech and Slovak households showed that the average overall amount of monthly income per household member is slightly lower than the income of an average senior living in their own household. This finding proves that the average income level of seniors is comparable to the income level in the entire society. The observed twelve-year period also showed the same rate of revenue growth in both groups. The group of seniors living alone appears to be the most vulnerable in terms of income insufficiency. This means that if the senior person stays alone in their household, either by their own decision or because of their partner's death, they become "socially" but also "financially" vulnerable. As for social threats, we primarily consider the danger of social exclusion, or social isolation. In the case of income deficit, we are talking about the threat of poverty. However, the two risks (social and economic) examined are not the only ones that endanger the life situation of senior citizens living in single-person households. It is also affected by other threats related to age and health (either psychological or physical). In the area of social policy, we can talk about multidimensional, multi-aspect threats. All dimensions of threats 
need to be reflected when designing public and social policy programs, i.e. the programs must reflect specifics of the targeted subgroups, such as the seniors living in single-person households. The income inequality of seniors, or its equality, points to the high emphasis laid on solidarity in the pension systems in the Czech Republic and Slovakia. The difference between income and expenditures of seniors, which is apparent from the decile distribution, is evidenced by the fact that approximately $40 \%$ of seniors live near the poverty line (very low fluctuations in financial amounts oscillating around this line were identified), where any unforeseen expenditure can push them below the poverty line. The most threatened seniors are those who live alone, i.e. in single-person households. Based on the obtained results, we have concluded that the senior population is becoming poor, with increasing numbers of materially deprived persons in the senior age. However, it should be noted that the degree of life satisfaction in the old age is positively affected by the expressed value system and by the level of achieved education.

\section{REFERENCES}

Bradley, F. J. (2004): Active Aging and Self-Esteem. The Gerontologist 44(5): 724-725.

Boudiny, K. (2013): Active Ageing: From Empty Rhetoric to Effective Policy Tool. Ageing and Society 33(6): 1077-1098.

Chakravarty, S. R. (2010): Inequality, Polarization and Poverty. New York: Springer.

CZSO (2015): Počet obyvatel v obcich $-k$ 1. 1. 2015. Počet obyvatel v regionech soudržnosti, krajich a okresech České republiky k 1. 1. 2015 [Population in Municipalities - on 1 January 2015. Population in Cohesion Regions, Regions and Districts of the Czech Republic on 1 January 2015]. Prague: ČSÚ. https://www.czso.cz/csu/czso/pocet-obyvatel-v-obcich-k-112015, accessed 29/12/2016.

CZSO (2016a): Česká republika v mezinárodním srovnání (vybrané údaje) - Složení obyvatelstva podle věkových skupin [Czech Republic in International Comparison (Selected Data) - Population Composition by Age Groups]. Prague: ČSÚ. https://www.czso.cz/csu/czso/obyvatelstvo, accessed: 29/12/2016.

CZSO (2016b): Česká republika v mezinárodním srovnání (vybrané údaje) - Naděje dožití při narozeni [Czech Republic in International Comparison (Selected Data) - Expectancy of Life Survival at Birth]. Prague: ČSÚ. https://www.czso.cz/csu/czso/obyvatelstvo, accessed: 29/12/2016.

CZSO (2016c): Klasifikace vzdèláni (CZ-ISCED 2011) [Classification of Education (CZ-ISCED 2011)]. Prague: ČSÚ. https://www.czso.cz/csu/czso/klasifikace_vzdelani_cz_isced_2011, accessed 29/12/2016.

Čevela, R. - Kalvach, Z. - Čevelová, L. (2012): Sociální gerontologie: Úvod do problematiky [Social Gerontology: Introduction]. Prague: GRADA.

Eurostat (2017): Housing Statistics - Housing Quality. http://ec.europa.eu/eurostat/statisticsexplained/index.php/Housing_statistics\#Housing.quality, accessed 03/01/2017.

Eurostat (2018a): EU Statistics on Income and Living Conditions (EU-SILC). Methodology. https:// ec.europa.eu/eurostat/statistics-explained/index.php/EU_statistics_on_income_and_living_ conditions_(EU-SILC)_methodology___introduction, accessed 20/05/2019. 
Eurostat (2018b): Glossary: Material Deprivation. https://ec.europa.eu/eurostat/statistics-explained/ index.php?title=Glossary:Material_deprivation, accessed 20/09/2018.

Eurostat (2019): Database - Income and Living Conditions. https://ec.europa.eu/eurostat/web/ income-and-living-conditions/data/database, accessed 20/05/2019.

EUR-Lex (2013): Regulation (EC) No 1177/2003 of the European Parliament and of the Council of 16 June 2003 concerning Community statistics on income and living conditions (EU-SILC). https://eur-lex.europa.eu/legal-content/EN/TXT/HTML/?uri=CELEX:32003R1177\&from=E $\mathrm{N}$, accessed 20/05/2019.

Frankl, V. E. (2015): Lékařská péče o duši [Medical Soul Care]. Brno: Cesta.

Frankl, V. E. (2016a): A přesto řici životu ano: psycholog proživá koncentračni tábor [Despite Saying Yes to Life, a Psychologist is Experiencing a Concentration Camp]. Kostelní Vydř́: Karmelitánské nakladatelství.

Frankl, V. E. (2016b): Utrpení z nesmyslnosti života: psychoterapie pro dnešni dobu [Suffering from the Pointlessness of Life: Psychotherapy for Today]. Prague: PORTÁL.

Gruss, P. (2009): Perspektivy stárnutí [Perspectives of Ageing]. Prague: PORTÁL.

Halleröd, B - Larsson, D. (2008): Poverty, Welfare Problems and Social Exclusion. International Journal of Social Welfare 17(1): 15-25.

Holmerová, I. - Jurašková, B. - Rokosová, M. - Vaňková, H. - Veleta, P. (2006): Aktivní stárnutí [Active Ageing]. Česká geriatrická revue 4(3): 63-68.

Keller, J. (2009): Soumrak sociálního státu [Dusk of the Welfare State]. Prague: SLON.

Kis, A. B. - Gábos, A. (2015): Consistent Poverty across the EU. Improve Discussion Paper. $15 / 22$.

Kubalčíková, K. - Havlíková, J. - Hubíková, O. - Dohnalová, Z. (2015): Sociální práce se seniory $v$ kontextu kritické gerontologie [Social Work with Seniors in the Context of Critical Gerontology]. Brno: Masarykova univerzita.

Mareš, P. - Horáková, M. - Rákoczyová, M. (2008): Sociální exkluze na lokální úrovni [Social Exclusion at Local Level]. Prague: VÚPSV.

MPSV (2002): Madridský mezinárodní akčni plán pro problematiku stárnutí [Madrid International Action Plan on Ageing]. Prague: MPSV. http://www.mpsv.cz/files/clanky/1205/madrid.pdf, accessed 24/12/2016.

MPSV (2014): Národni akčni plán podporujicí pozitivni stárnutí pro obdobi 2013 až 2017 [National Action Plan for Positive Ageing for 2013-2017 Period]. Prague: MPSV. http://www. mpsv.cz/files/clanky/20851/NAP_311214.pdf, accessed 15/12/2016.

MPSV (2015): Zpráva o plnění Národního akčního plánu podporujícího pozitivní stárnutí pro obdobi let 2013 až 2017 za rok 2014 [Report on the Implementation of the National Action Plan Promoting Positive Ageing for the Period 2013-2017 and for the Year 2014]. Prague: MPSV. http://www.mpsv.cz/files/clanky/21668/Zprava_o_plneni_NAP_214.pdf, accessed 23/12/2016.

MPSV (2016): Rada vlády pro seniory a stárnutí populace [Government Council for Seniors and Population Ageing]. Prague: MPSV. http://www.mpsv.cz/cs/2897, accessed 23/12/2016.

Nekola, M. - Geissler, H. - Mouralová, M. (2011): Současné metodologické otázky veřejné politiky [Current Methodological Issues of Public Policy]. Prague: Karolinum.

OECD (2015): Ageing: Debate the Issues. Paris: OECD Publishing.

Pisarev, A. V. (2006): Factors of Employment in Retirement Age. Sociological Research 45(1): 59-77.

Piscová, M. (2014): Starnutie a starší l’udia: Podmienky a súvislosti [Ageing and Older People: Conditions and Context]. Bratislava: Sociologický ústav SAV.

Potančoková, M. Starnutie populácie Slovenska [Ageing of the Slovak Population]. http://www. infostat.sk/vdc/pdf/StarnutieVDC.pdf, accessed 15/04/2018. 
Potůček, M. - Radičová, I. (1999): Sociální politika v Čechách a na Slovensku po roce 1989 [Social Policy in the Czech Republic and Slovakia after 1989]. Prague: Karolinum.

SO SR (2019): Databáza DATAcube [Database DATAcube]. http://datacube.statistics.sk, accessed 21/01/2018.

Stiglitz, J. E. - Sen, A. - Fitoussi, J. (2009): Report by the Commission on the Measurement of Economic Performance and Social Progress. http://ec.europa.eu/eurostat/documents/118025/118123/ Fitoussi+Commission+report, accessed 28/03/2019.

Sýkorová, D. (2007): Autonomie ve stárí: kapitoly z gerontosociologie [Autonomy in Old Age: Chapters from Gerontosociology]. Prague: SLON.

Sýkorová, D. - Nytra, G. - Tichá, I. (2014a): Bydleni v kontextu chudoby a stáři [Living in the Context of Poverty and Old Age]. Ostrava: Ostravská univerzita v Ostravě.

Sýkorová, D. - Tichá, I. - Nytra, G. (2014b): Výzkum chudoby ve stáři [Research on Poverty in Old Age]. In: Baum, D. - Gojová, A. (eds): Research Methods in Social Work. Ostrava: Ostravská univerzita v Ostravě.

Šprocha, B. - Vaňo, B. - Jurčová, D. - Pilinská, V. - Mészáros, J. - Bleha, B. (2015): Populačný vývoj v Slovenskej republike 2014 [Population Development in the Slovak Republic 2014]. Bratislava: INFOSTAT. http://www.infostat.sk/vdc/pdf/Populacny_vyvoj_SR_2014.pdf, accessed $15 / 04 / 2018$.

Vágnerová, M. (2007): Vývojová psychologie II.: Dospělost a stáři [Developmental Psychology II: Adulthood and Old Age]. Prague: KAROLINUM.

Vávrová, S. (2015): Decision-Making in Seniors Regarding Residential Social Services. Procedia - Social and Behavioral Sciences 174: 908-915.

Veselý, A. - Nekola, M. (2007): Analýza a tvorba veřejných politik (přistupy, metody a praxe) [Analysis and Creation of Public Policies (Approaches, Methods and Practices)]. Prague: SLON.

WHO (2002): Active Ageing: A Policy Framework. Madrid: WHO. http://apps.who.int/iris/ bitstream/10665/67215/1/WHO_NMH_NPH_02.8.pdf, accessed 29/12/2016.

Open Access. This is an open-access article distributed under the terms of the Creative Commons Attribution-NonCommercial 4.0 International License (https://creativecommons.org/licenses/by-nc/4.0/), which permits unrestricted use, distribution, and reproduction in any medium for non-commercial purposes, provided the original author and source are credited, a link to the CC License is provided, and changes - if any - are indicated. 